\title{
BIOCOMPOSITES BASED ON POLYLACTIC ACID AND THEIR THERMAL BEHAVIOR AFTER RECYCLING
}

\author{
Vineta Srebrenkoska $^{1 *}$, Gordana Bogoeva-Gaceva $^{2}$, Dimko Dimeski $^{1}$ \\ ${ }^{1}$ Faculty of Technology, Goce Delčev University, Krste Misirkov b.b., 2000 Štip, \\ Republic of Macedonia \\ ${ }^{2}$ Faculty of Technology and Metallurgy, Ss.Cyril and Methodius University, 1000 Skopje, \\ Republic of Macedonia \\ vineta.srebrenkoska@ugd.edu.mk, dimko.dimeski@ugd.edu.mk, gordana@tmf.ukim.edu.mk
}

In this study, rice-hull-filled polylactic acid (PLA) biocomposites were prepared through the addition of 5 wt.\% PLA-grafted-MA (CA) for the enhancement of adhesion between the polymer matrix and natural filler. The composites containing $30 \mathrm{wt}$ \% rice hulls $(\mathrm{RH})$ were prepared by compression molding, with particular attention given to the introduction of recycled PLA matrix, as well as to the possibility of the recycling and reuse of PLA/RH biocomposites. For all biocomposites, produced from neat polymer and RH and those produced after the recycling of PLA/RH composites, the mechanical and thermal properties were analyzed and compared to those of a commonly used thermoplastic based-polymer, polypropylene (PP), containing the same reinforcement. Thermal stability of biocomposites based on recycled PLA matrix and of the new composites produced from recycled ones was practically unchanged. Introduction of the recycled PLA matrix into biocomposites resulted in decreased flexural modulus and strengths of about $50 \%$. Utilization of the mixture obtained after the thermal-mechanical recycling of the whole biocomposite resulted in a composite with slightly increased flexural modulus and decreased flexural strength.

The obtained results have shown that rice-hull-filled poly(lactic acid) biocomposites could be recycled and utilized for the production of new eco-materials with acceptable thermal and mechanical properties. Namely, the results for flexural strength and modulus of the recycled biocomposite samples are comparable to those of conventional formaldehyde wood medium density fiberboards used as construction elements for indoor applications.

Keywords: biocomposites; polylactic acid; polypropylene; rice hulls; compression molding

\section{БИОКОМПОЗИТИ НА БАЗА НА ПОЛИМЛЕЧНА КИСЕЛИНА И НИВНИ ТЕРМИЧКИ КАРАКТЕРИСТИКИ ПО РЕЦИКЛИРАЊЕ}

Подготвени се биокомпозити полимлечна киселина/оризови лушпи со додавање на $5 \%$ калем-кополимер полимлечна киселина-ко-малеински анхидрид, PLA-graft-MA, како компатибилизатор за подобрување на атхезијата помеѓу полимерната матрица и природното полнило. Композитите со $30 \%$ оризови лушпи (RH) беа подготвени по пат на пресување, при што особено внимание е посветено на внесување рециклирана полимлечна киселина, како и на можност за рециклирање и повторна употреба на биокомпозитите PLA/RH. Кај биокомпозитите произведени од нерециклиран полимер и RH, како и кај оние произведени од рециклираните композитни материјали, анализирани се механичките и термичките својства, кои се споредувани со оние на конвенционалните термопластични композити на база на полипропилен (PP), зајакнат со истото полнило. Термичката стабилност на биокомпозитите од рециклирана PLA матрица, како и на оние произведени од рециклиран композит, е практично непроменета. Внесувањето на рециклирана матрица во биокомпозитите резултира во намалување на модулот и јачината на свиткување за околу 50 \%. Искористувањето на смесите добиени по термо-механичкото рециклирање на целиот 
биокомпозит резултира во добивање нов композит со незначително зголемен модул и намалена јачина на свиткување.

Добиените резултати покажаа дека биокомпозитите полимлечлна киселина/оризови лушпи можат да бидат подложени на рециклирање и повторно да се употребат за производство на нови еколошки материјали со прифатливи термички и механички својства. Имено, резултатите за јачината и модулот на свиткување на рециклираните биокомпозитни примероци се споредливи со оние на конвенционалните формалдехидни пресувани плочи со средна густина, кои се користат како градежни елементи за внатрешно уредување.

Клучни зборови: биокомпозити; полимлечна киселина; оризови лушпи; пресување

\section{INTRODUCTION}

Recently, the use of renewable resources for the production of polymer-based materials has attracted growing attention, both in academia and industry, as a result of the increasing demand of environmentally friendly materials [1]. The development of eco-composites (based on recyclable thermoplastics) as well as biocomposites (based on biodegradable polymers) and natural fibers as reinforcement has accelerated rapidly, primarily due to improvements in process technology and economic factors. These materials could allow complete degradation in soil or by composting process and do not emit any toxic or noxious components $[1,2]$. Many investigations have been performed regarding the potential use of different natural fibers as reinforcements for eco-composites (composite material with environmental and ecological advantages over conventional composites) and the results have shown that they exhibit good stiffness and promising properties [1-8]. Natural fibers from renewable sources represent an environmentally friendly alternative to conventional reinforcing fibers (glass, carbon, Kevlar). The advantages of natural fibers over traditional ones are low cost, high toughness, low density, good specific strength properties, reduced tool wear (nonabrasive to processing equipment), enhanced energy recovery, the fact that they are $\mathrm{CO}_{2}$ neutral when burned, and their biodegradability. The main drawback of natural fibers is their hydrophilic nature, which prevents their compatibility with hydrophobic polymers used as matrices for the production of composite materials; therefore, different kinds of coupling agents have been used to improve interfacial adhesion between polymer matrices and natural fibers in order to enhance the physical and mechanical properties of the final products [9].

Depending on their performance, when they are included in polymer matrices, lignocellulosic fibers can be classified into three categories: (1) wood flour particulates, which increase the tensile and flexural modulus of the composites, (2) fibers (higher aspect ratio), that contribute to improving the composite modulus and strength when suitable additives are used to optimize the stress transfer between the matrix and the fibers, and (3) long natural fibers, with the highest efficiency amongst the lignocellulosic reinforcements. The most efficient natural fibers have been considered those showing a high cellulose content coupled with a low microfibril angle, resulting in the best composite mechanical properties $[10,11]$.

On the other hand, the development of wholly biodegradable polymers and polymeric materials can play a fundamental role in helping to solve the waste disposal problems [12, 13]. Among biodegradable plastics, polylactic acid (PLA), produced on a large scale from the fermentation of corn starch to lactic acid and subsequent chemical polymerization, exhibits excellent mechanical properties, good heat resistance coupled with moldability, and recyclability. This polymer is characterized by its transparency, humidity and oil resistance. Pure PLA can degrade to carbon dioxide, water and methane in the environment over a period of several months to 2 years, compared to other petroleum plastics needing much longer periods $[5,6,7]$. The mechanical properties of PLA have been extensively studied as a biomaterial in the medicine, but only recently has it been used as a polymer matrix in eco-composites [8], although its application is still limited by its relatively high price when compared with some other biodegradable polymers. Kenaf fibers have already been tested as natural reinforcement for polyolefins, but there is a growing interest in the preparation of biocomposites $[14,15]$. Xia et al. [9] investigated the use of PLA resin reinforced with kenaf fibers for the interior parts of its Prins hybrid car. In 2002, Cargill-Dow LLC started up a commercial polylactide plant, with the aim of producing PLA fibers for textiles and nonwovens, PLA film packaging applications, and rigid thermoformed PLA containers [16].

In our previous study $[17,18,19,20]$, compatibilization strategy was developed for PLA and 
PP-based composites, and utilization of reinforcements from renewable sources for eco-composites was investigated [21].

The purpose of this study was to investigate the recycling ability of the materials based on a biodegradable PLA matrix. The PLA was recycled and the rice hull fillers were compounded with the polymer matrix and coupling agent by melt mixing; the obtained compounds were then compression molded. Also, the biocomposites were further granulated and blended two times by melt mixing, followed by compression molding of new samples. Finally, the influence of the recycling process on the properties of composites was evaluated through the mechanical and thermal characterization of the composites.

This work is a follow-up of the successfully completed ECO-PCCM project [22], in which ecocomposites based on PLA, PHBV and PP were prepared and investigated in order to obtain new eco-friendly construction panels and elements for eco-houses [19, 20].

\section{EXPERIMENTAL}

\subsection{Materials}

Polylactic acid used as a matrix in the composites was supplied by Biomer (Krailling-Germany), whilst the waste rice hulls used as a filler were kindly supplied by the Rice Institute of Kočani, R. Macedonia. The matrix was recycled once (PLAx1) by an extrusion procedure with a twin-screw extruder. Sigma-Aldrich reagent products (SteinheimGermany), maleic anhydride (MA) and dibenzoylperoxide (DBPO) were used as received.

PLA-g-MA, used as a coupling agent, was prepared through reactive mixing in a Brabenderlike apparatus of $48.5 \mathrm{~g}$ PLA (previously mixed for
5 minutes at $170{ }^{\circ} \mathrm{C}$ ), and a mixture of $1.5 \mathrm{~g} \mathrm{MA}$ and $0.75 \mathrm{~g}$ DBPO. The reactive mixing was performed at $180{ }^{\circ} \mathrm{C}$ for 5 minutes, progressively increasing the mixing speed up to $32 \mathrm{rpm}$. Finally, the obtained material was dried under a vacuum at $100{ }^{\circ} \mathrm{C}$ in order to remove unreacted maleic anhydride. More details concerning the synthesis and characteristics of CA are presented earlier in [17].

\subsection{Compounding of composite materials}

Composites with 30 wt.\% rice hull loading, as well as corresponding ones where part of the PLA matrix was replaced with a CA, PLA/RH/CA (65/30/5 wt.\%), were prepared by extrusion in HAAKE Rheocord (New Jersey, USA) at $T=$ $175^{\circ} \mathrm{C}$ using a defined combination of mixing time and screws rotation speed ( 3 min with $8 \mathrm{rpm}, 4 \mathrm{~min}$ with $16 \mathrm{rpm}$ and $3 \mathrm{~min}$ with $32 \mathrm{rpm}$ ). Prior to extrusion, the ingredients were mixed and afterward added to the extruder heated to a predefined temperature. Concerning the composites prepared with coupling agent, a mixture of pure and modified PLA was initially prepared during $3 \mathrm{~min}$ with $8 \mathrm{rpm}$, and afterward the rise hulls were added.

Our further task was to examine the recycling behavior of the biocomposite itself by analyzing the properties of re-processed composites produced from the recycled ones. In order to evaluate the response of composites to the recycling process in terms of mechanical properties, the obtained materials were successively reprocessed under the same preparation conditions as described for the starting PLA/RH/CA biocomposites.

Before the extrusion, the milled rice hulls agricultural waste were vacuum-dried for $24 \mathrm{~h}$.

The codes of the samples obtained are shown in Table 1.

Table 1

Codes of composite samples produced by compression molding using neat or recycled polymer as a matrix, and produced from wholly recycled composites

\begin{tabular}{|c|c|c|c|c|c|c|c|}
\hline \multirow[b]{2}{*}{ Codes } & \multirow[b]{2}{*}{ Description } & \multicolumn{2}{|c|}{ Matrix (wt.\%) } & \multicolumn{2}{|c|}{ Fiber/Filler } & \multicolumn{2}{|c|}{ Coupling agent (CA) } \\
\hline & & Type & $\begin{array}{c}\text { Content } \\
\text { (wt. \%) }\end{array}$ & Type & $\begin{array}{c}\text { Content } \\
\text { (wt.\%) }\end{array}$ & Type & $\begin{array}{c}\text { Content } \\
\text { (wt. \%) }\end{array}$ \\
\hline PLA/RH & Neat & PLA & 70 & \multirow{5}{*}{$\begin{array}{l}\text { Rice } \\
\text { Hulls }\end{array}$} & \multirow{5}{*}{30} & I & I \\
\hline PLA/RH/CA & Neat & PLA & \multirow{4}{*}{65} & & & \multirow{4}{*}{ MAPLA } & \multirow{4}{*}{5} \\
\hline $\mathrm{PLA} \times 1 / \mathrm{RH} / \mathrm{CA}$ & $\begin{array}{l}\text { Composite with } \\
\text { recycled matrix }\end{array}$ & $\begin{array}{c}\text { PLA re- } \\
\text { cycled once }\end{array}$ & & & & & \\
\hline $\mathrm{PLA} / \mathrm{RH} / \mathrm{CA}(\times 1)$ & $\begin{array}{l}\text { Composite } \\
\text { recycled once }\end{array}$ & \multirow{2}{*}{ PLA } & & & & & \\
\hline PLA/RH/CA $(\times 2)$ & $\begin{array}{l}\text { Composite } \\
\text { recycled two } \\
\text { times }\end{array}$ & & & & & & \\
\hline
\end{tabular}




\subsection{Compression molding}

The samples for mechanical testing were fabricated by compression molding in a CARVER press. The pellets obtained after melt mixing of starting materials were put in molding frame with desired dimensions and compression molded at $T=$ $175^{\circ} \mathrm{C}$ for 10 minutes, with progressively increasing pressure from 50 to 150 bar. Finally, the press was cooled using a cold water flow. Sheets with a thickness of about $5 \mathrm{~mm}$ were obtained.

\subsection{Methods}

Mechanical and thermal properties of the composites such as impact resistance (Charpy impact test according ASTM D 256), compression strength (ASTM D 695), flexural strength and the modulus (ASTM D 790) were determined. For all mechanical tests, the universal testing machines (Schenk and Frank, Germany) were used. The thermal stability of composites was analyzed using a Perkin Elmer Pyris Diamond Thermogravimetrical Analyzer (TGA). About $10 \mathrm{mg}$ of each sample was heated from $50{ }^{\circ} \mathrm{C}$ to $600{ }^{\circ} \mathrm{C}$ at a heating rate of $20^{\circ} \mathrm{C} \cdot \mathrm{min}^{-1}$ under nitrogen flow $\left(25 \mathrm{ml} \cdot \mathrm{min}^{-1}\right)$. Morphological analysis was performed by using a JEOL scanning electron microscope (SEM), on cryogenically fractured surfaces of composite samples. Before the observation, the specimens were metallized with a gold/palladium coating in a Polaron Sputtering.

\section{RESULTS AND DISCUSSION}

\subsection{Mechanical analysis}

In our previous studies, we investigated the properties of a new class of biodegradable PLAbased composites reinforced with kenaf fibers produced with or without compatibilizing agent [12]. Also, the effects of compatibilization on the performance of PHBV-based biocomposites was evaluated [18, 23].

The main goal of this work was the preparation and characterization of PLA-based biocomposites produced from a neat and recycled matrix and reinforced with rice hulls, with particular attention paid to possibility of their reuse. For this purpose, the mechanical properties of the recycled polymer matrix were first compared to neat polymer, and the mechanical properties of the composites produced from recycled matrices were compared to composites with neat PLA. The mechanical properties of the polymer remain practically unchanged after recycling: flexural strength for neat and recycled PLA is $32.0 \mathrm{MPa}$.

PLA biocomposites were first prepared by a proper in situ reactive compatibilization, a strategy inducing a strong interfacial filler (fiber)/polymer adhesion and thus resulting in improvement of the mechanical properties [24].

The coupling agents used for compatibilization are constituted from PLA segments (the same as the polymer matrix) and by MA groups grafted onto PLA segments, which become reactive with respect to the hydroxyl groups present on the reinforcement surface. In this way, physical and/or chemical interactions between hydroxyl and maleic anhydride groups, generated during the mixing, are responsible for the grafted species formed in situ that can act as effective compatibilizers for the PLA/natural fiber/filler reinforcement composites $[25,26]$.

Table 2 shows a summary of the flexural properties for rice hull-based composites with neat and recycled matrices and for whole recycled composites.

Table 2

Flexural properties of biocomposites produced with neat and recycled matrices and for recycled composites

\begin{tabular}{lcc}
\hline \hline Sample & $\begin{array}{c}\text { Stress at peak } \\
(\mathrm{MPa})\end{array}$ & $\begin{array}{c}\text { Modulus } \\
(\mathrm{GPa})\end{array}$ \\
\hline PLA & $32.0 \pm 2.8$ & $2.4 \pm 0.14$ \\
PLA/RH & $13.9 \pm 3.4$ & $3.0 \pm 0.21$ \\
$(70 / 30$ wt. $\%)$ & $(-56.6 \%)^{\mathrm{a}}$ & $(+25.0 \%)^{\mathrm{a}}$ \\
PLA / RH /CA & $28.8 \pm 6.6$ & $3.2 \pm 0.18$ \\
$(65 / 30 / 5$ wt.\%) & $(-3.5 \%)^{\mathrm{a}}$ & $(+33.3 \%)^{\mathrm{a}}$ \\
PLAx1 / RH /CA & $14.8 \pm 1.3$ & $2.3 \pm 0.46$ \\
(65/30/5 wt.\%) & $(-48.6 \%)^{\mathrm{b}}$ & $(-28.1 \%)^{\mathrm{b}}$ \\
PLA/RH /CA (x1) & $12.1 \pm 4.8$ & $3.24 \pm 0.38$ \\
(65/30/5 wt.\%) & $(-58.0 \%)^{\mathrm{b}}$ & $(+1.25 \%)^{\mathrm{b}}$ \\
PLA/RH /CA (x2) & $10.7 \pm 2.5$ & $3.32 \pm 0.18$ \\
(65/30/5 wt.\%) & $(-62.8 \%)^{\mathrm{b}}$ & $(+3.75 \%)^{\mathrm{b}}$ \\
\hline \hline
\end{tabular}

${ }^{\mathrm{a}}$ In brackets are the percentage changes of the corresponding property, compared to the value for neat PLA.

${ }^{\mathrm{b}}$ In brackets are the percentage changes of the corresponding property, compared to the value for neat composite PLA/RH/CA.

Incorporation of rice hulls into the PLA matrix produced an increase in the flexural modulus, reaching 3.0 GPa for composite PLA/RH (70/30 wt.\%), and a drop in the stress at a peak of around $57 \%$. However, the presence of a coupling agent in PLA/RH composites doubled the stress at peak in flexure value. Composite PLA/RH/CA (65/30/5 wt.\%) exhibited stress at peak in flexure of almost 
$29 \mathrm{MPa}$, which is close to the value displayed by pure PLA. Modulus in flexure increased in the presence of a coupling agent. The extent of the modulus improvement is correlated to the filler/matrix interfacial adhesion, thus justifying the highest modulus value obtained in the presence of a reactive coupling agent. Significant deterioration of flexural properties is seen for recycled PLAbased composites. The reason for this is probably a decline in the molecular weight of PLA during the recycling procedure and also changes induced in the morphology of the reinforcement caused by repeated kneading (as pointed out by high determined values for standard deviation).

The flexural strength of PLA/RH/CA (65/30/5 wt.\%) recycled composites decreased by about $50 \%$ after recycling, although the flexural modulus was practically unchanged. As reported in the literature, the recycling process of polymer/fiber composites frequently induces a decrease in the physical properties of composites. The extent of this decrease is strictly correlated to the decline in the molecular weight of the polymer matrix and to the deterioration of fibers/fillers in terms of length caused by repeated kneading [27].

In the framework of this investigation, the recycling behavior and overall characteristics of PLA-based biocomposites were also compared to composites based on a commonly used thermoplastic polymer, polypropylene, containing the same reinforcement. For that aim, PP-based composites were produced and their recycling behavior and overall properties were determined. Although PP could not be classified as a biodegradable polymer, this thermoplastic polymer takes an important place amongst eco-composites [10], primarily due to its recyclability, low cost and good price/performance ratio. Mohanty et al. [16] reported that PP can be effectively modified by maleic anhydride, providing polar interactions and covalent bonds between the matrix and the hydroxyl groups of cellulose fibers. The preparation of the PP-based composites was performed in the same way as PLA-based biocomposites - by melt mixing of the composite compounds and their subsequent compression molding. PP-g-MA was used as a coupling agent, prepared through reactive mixing, as reported in the experimental section for PLA-g-MA.

The values obtained for PP-based composites for flexural strength and modulus are similar to those of neat PP (Table 3). The recycling processes for these composites induces a slight decrease in the flexural strength after the second recycling (about 5\%) and an increase in the flexural modulus (about 20\%). As expected, the PLA- based biocomposites have lower mechanical properties than the PP-based ones, but significant deterioration of flexural properties has been seen for the recycled PLA-based biocomposites. Nevertheless, it is well known that polyolefins are less sensitive to reprocessing than other polymers such as polyesters. Therefore, unless recycling processes can induce beta-scission in the polymer matrix, the possible molecular weight decrease due to the reprocessing does not seem to significantly affect the mechanical properties of the PP-based composites reinforced with rice hulls. With regard to PLAbased biocomposites, our further investigations are directed towards the possibility of improving their stability during the re-processing cycle, which will be the subject of our future publication.

Table 3

Flexural properties of PP-based composites produced with neat and recycled matrices and for recycled composites

\begin{tabular}{|c|c|c|}
\hline Sample & $\begin{array}{l}\text { Stress at peak } \\
(\mathrm{MPa})\end{array}$ & $\begin{array}{c}\text { Modulus } \\
(\mathrm{GPa})\end{array}$ \\
\hline PP & $51.5 \pm 5.5$ & $1.1 \pm 0.12$ \\
\hline PP/RH (70/30wt.\%) & $31.6 \pm 2.4$ & $0.9 \pm 0.31$ \\
\hline $\begin{array}{l}\mathrm{PP} / \mathrm{RH} / \mathrm{CA} \\
(65 / 30 / 5 \mathrm{wt} . \%)\end{array}$ & $42.6 \pm 3.4$ & $1.9 \pm 0.08$ \\
\hline $\begin{array}{l}\mathrm{PPx} 1 / \text { RH /CA } \\
(65 / 30 / 5 \mathrm{wt} \%)\end{array}$ & $42.2 \pm 1.2$ & $1.8 \pm 0.04$ \\
\hline $\begin{array}{l}\text { PPx2 / RH /CA } \\
\text { (65/30/5wt.\%) }\end{array}$ & $39.6 \pm 4.6$ & $1.8 \pm 0.06$ \\
\hline $\begin{array}{l}\mathrm{PP} / \mathrm{RH} / \mathrm{CA}(\mathrm{x} 1) \\
(65 / 30 / 5 \mathrm{wt} . \%)\end{array}$ & $44.8 \pm 3.0$ & $1.88 \pm 0.16$ \\
\hline $\begin{array}{l}\text { PP/RH /CA (x2) } \\
(65 / 30 / 5 \text { wt. } \%)\end{array}$ & $38.5 \pm 7.2$ & $1.91 \pm 0.06$ \\
\hline
\end{tabular}

Oksman et al. [5] studied the recycling properties of the PLA/kenaf composite. The physical properties and molecular weight were close to $90 \%$ of that of the initial PLA/kenaf composites. The physical properties of the PLA/kenaf composite can probably be kept constant by adjustment of the ratio of the initial PLA/kenaf composite and the recycled one. Sanadi et al. [28] studied the possibility of using highly filled agro-based fiber thermoplastic composites for furniture, automotive and building applications. They showed that the performances of thermoplastic-based composites are better than most wood particles, low and medium density fiberboards. The composites investigated show flexural properties comparable to conventional formaldehyde-based fiberboards [28]. Moreover, these parameters remain similar to those of 
formaldehyde-based wood composites also after the recycling processes.

\subsection{Thermal stability of PLA-biocomposites and their behavior after recycling}

The thermal stability of biocomposites produced from neat and recycled matrix, as well as from wholly recycled composite, was analyzed by TGA/DTG.

Results from the thermogravimetric analyses of PLA, rice hulls and the biocomposite PLA/ RH/CA (65/30/5 wt.\%) are presented in Figure 1a and Table 4. As can be seen, rice hulls undergo a two-step weight loss process: below $110^{\circ} \mathrm{C}$, weight loss resulted from the evaporation of absorbed moisture, and in the temperature range between 170 and $500{ }^{\circ} \mathrm{C}$, this resulted from the degradation of the three major constituents of rice hulls. The lignocellulosic materials are chemically active and decompose thermo-chemically between 150 and $500{ }^{\circ} \mathrm{C}$ : hemicellulose mainly between 150 and $350{ }^{\circ} \mathrm{C}$, cellulose between 275 and $350{ }^{\circ} \mathrm{C}$, and lignin between 250 and $500{ }^{\circ} \mathrm{C}$. Ash in the rice husk (12\%) is mainly composed of silica ( $96 \%)$, and the amount and distribution of silica in the rice husk is likely to be an important factor in determining the composite products properties [29, 30]. PLA gradually loses $10 \%$ of its weight until $350{ }^{\circ} \mathrm{C}$, and then suffers almost complete weight loss in a temperature interval from $350^{\circ} \mathrm{C}$ to $400{ }^{\circ} \mathrm{C}$. The PLA-based composite PLA/RH/CA $(65 / 30 / 5$ wt.\%) loses $10 \%$ of its weight until $300{ }^{\circ} \mathrm{C}$, followed by ongoing $75 \%$ weight loss to $360-365^{\circ} \mathrm{C}$; after that, weight loss continues with a slower degradation rate. It should be noted that at a temperature of $600{ }^{\circ} \mathrm{C}$, rice hulls exhibit high residual weight of $39.7 \%$. These findings are in accordance with the findings of Lee et al. [31], who showed that the thermal stability of PLA/bamboo fiber composites is lower than the thermal stability of neat PLA matrix.

Derivative thermogravimetric curves for neat PLA, rice hulls and their composite PLA/RH are presented in Figure 1b. Maximum weight loss rate for PLA $\left(3.37 \% \cdot{ }^{\circ} \mathrm{C}^{-1}\right)$ is reached at $362.9^{\circ} \mathrm{C}$, and for rice hulls, weight loss rate is uppermost $\left(0.72 \%{ }^{\circ} \mathrm{C}^{-1}\right)$ at $342.1^{\circ} \mathrm{C}$. Composite PLA/RH/CA $(65 / 30 / 5$ wt. $\%)$ exhibits a maximum weight loss rate of $1.93 \%{ }^{\circ} \mathrm{C}^{-1}$ at $343.2{ }^{\circ} \mathrm{C}$, a temperature that is almost $20^{\circ} \mathrm{C}$ lower than the corresponding one for neat PLA, proving again the previous finding of the insignificantly lower thermal stability of composites.

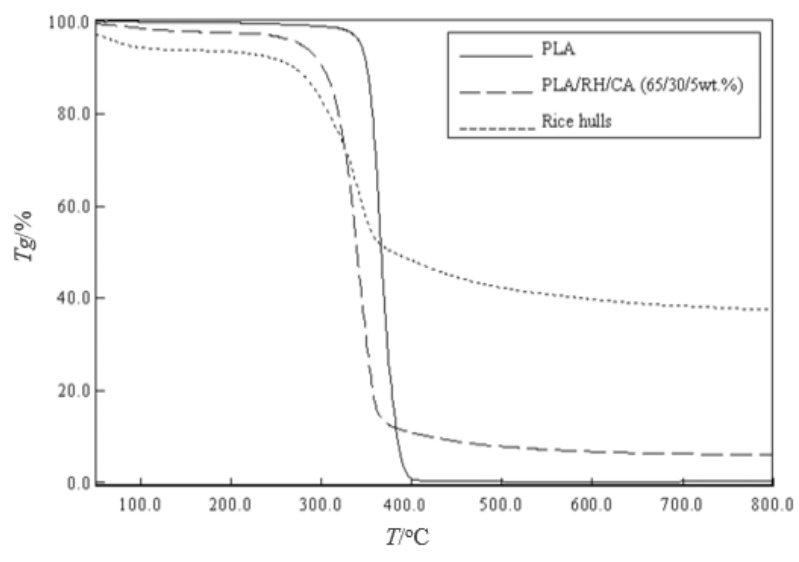

Fig. 1a. Thermogravimetric curves of PLA, rice hulls and PLA/RH/CA (65/30/5 wt.\%)

biocomposites: weight loss (\%) versus temperature

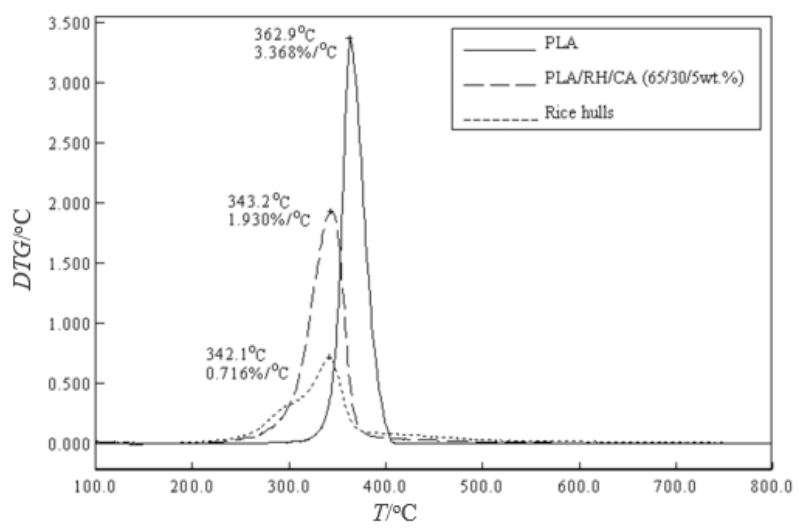

Fig. 1b. Derivative thermogravimetric curves of PLA, rice hulls and PLA/RH/CA (65/30/5 wt.\%) biocomposites: derivative weight loss $\left(\% \cdot{ }^{\circ} \mathrm{C}^{-1}\right)$ versus temperature

T a b le 4

Thermal stability of PLA, rice hulls and biocomposite PLA/RH/CA (65/30/5 wt.\%)

\begin{tabular}{cccc}
\hline \hline & \multicolumn{3}{c}{ Weight loss $(\%)$} \\
\cline { 2 - 4 }$T\left({ }^{\circ} \mathrm{C}\right)$ & $\begin{array}{c}\text { Rice } \\
\text { hulls }\end{array}$ & $\begin{array}{c}\text { PLA/RH/CA } \\
(65 / 30 / 5 w t . \%)\end{array}$ & Neat PLA \\
\hline 50 & 2.7 & 0.5 & 0 \\
100 & 5.6 & 1.4 & 0 \\
150 & 8.0 & 3.2 & 0.5 \\
290 & 14.0 & 6.9 & 0.9 \\
310 & 20.6 & 13.7 & 1.2 \\
330 & 29.7 & 33.5 & 2.1 \\
350 & 43.0 & 69.8 & 9.5 \\
370 & 49.1 & 86.9 & 61.3 \\
390 & 51.0 & 88.7 & 95.7 \\
410 & 52.6 & 89.7 & 99.6 \\
600 & 60.3 & 93.3 & 100 \\
\hline \hline
\end{tabular}

Further analyses of PLA recycled-based composites have shown that incorporation of the recycled matrix slightly affected the thermal degradation temperature (see Table 5). The compo- 
sites with recycled matrices showed a lower degradation temperature (less than $10^{\circ} \mathrm{C}$ ) than a composite with a neat matrix, and this effect could be attributed to the partial degradation, taking place by the repeatedly performed kneading of the polymers in air atmosphere. In the case of PP recycled-based composites (once and two times) which were investigated for comparison to biocomposites, a lower degradation temperature (less than $40^{\circ} \mathrm{C}$ ) could be noticed for a composite with a neat matrix. Dependent on the thermal behavior of the PP and PLA recycled-based composites, it may be noticed that there are no drastic changes in their thermal stability.

\section{Table 5}

Thermal stability of bio- and eco-composites produced from recycled matrices and recycled composites, as determined by TGA at a residual weight of $90 \%\left(T d_{90}\right), 50 \%\left(T d_{50}\right)$, and $10 \%\left(T d_{10}\right)$

\begin{tabular}{|c|c|c|c|}
\hline Sample & $\begin{array}{l}T d_{90} \\
\left({ }^{\circ} \mathrm{C}\right)\end{array}$ & $\begin{array}{l}T d_{50} \\
\left({ }^{\circ} \mathrm{C}\right)\end{array}$ & $\begin{array}{l}T d_{10} \\
\left({ }^{\circ} \mathrm{C}\right)\end{array}$ \\
\hline $\begin{array}{l}\text { PLA/RH/CA } \\
(65 / 30 / 5 \text { wt. } \%)\end{array}$ & 308.2 & 341.3 & 534.2 \\
\hline $\begin{array}{l}\text { PLAx 1/RH/CA } \\
(65 / 30 / 5 \text { wt. } \%)\end{array}$ & 299.42 & 341.70 & 529.70 \\
\hline $\begin{array}{l}\text { PLA/RH/CA (x1) } \\
(65 / 30 / 5 \text { wt. } \%)\end{array}$ & 294.4 & 323.8 & 517.3 \\
\hline $\begin{array}{l}\text { PLA/RH/CA (x2) } \\
(65 / 30 / 5 \text { wt. } \%)\end{array}$ & 289.1 & 319.5 & 501.1 \\
\hline $\begin{array}{l}\mathrm{PP} / \mathrm{RH} / \mathrm{CA} \\
(65 / 30 / 5 \text { wt. } \%)\end{array}$ & 344.43 & 411.21 & 452.17 \\
\hline $\begin{array}{l}\text { PPx1/RH/CA } \\
(65 / 30 / 5 \text { wt. } \%)\end{array}$ & 309.09 & 385.22 & 458.82 \\
\hline $\begin{array}{l}\mathrm{PPx} 2 / \mathrm{RH} / \mathrm{CA} \\
(65 / 30 / 5 \text { wt. } \%)\end{array}$ & 303.53 & 405.97 & 445.27 \\
\hline $\begin{array}{l}\text { PP/RH/CA (x1) } \\
(65 / 30 / 5 \text { wt. } \%)\end{array}$ & 336.7 & 409.9 & 471.0 \\
\hline $\begin{array}{l}\text { PP/RH/CA (x2) } \\
(65 / 30 / 5 \text { wt. } \%)\end{array}$ & 322.6 & 389.0 & 455.3 \\
\hline
\end{tabular}

We investigated the thermal behavior of the composites produced from wholly recycled ones, in terms of their sustainability values. The thermal degradation of one- and two-times recycled PLA/RH/CA (65/30/5 wt.\%) biocomposites proceeded in a single step, and occurred at $323.8^{\circ} \mathrm{C}$ $(\mathrm{PLA} / \mathrm{RH} / \mathrm{CA} \times 1)$ and $319.5^{\circ} \mathrm{C}(\mathrm{PLA} / \mathrm{RH} / \mathrm{CA} \times 2)$, respectively; the TG-curves have the same behavior. The recycled composites showed a lower degradation temperature (less than $20{ }^{\circ} \mathrm{C}$ ), exhibiting a decrease in the degradation temperature (of about $20{ }^{\circ} \mathrm{C}$ ) after the second recycling.

The results obtained from thermal analysis have shown that biocomposites based on PLA and rice hulls as reinforcement could be reused by recycling and re-forming; this process is more convenient than the recycling and reuse of the matrix itself.

\subsection{Morphological analysis}

The micrographs of composites containing 30 wt.\% rice hulls are presented in Figure 2. In PLA/RH (70/30 wt.\%) composite, rice hulls appeared to be poorly covered with the PLA matrix, thus indicating poor filler-polymer adhesion. Moreover, more plastic deformation of the PLA matrix in a glass state is evident from the present tips, which resulted from "neck" formation during material stressing (see micrograph a). An enhancement of adhesion level between the rice hulls and the matrix, in PLA/RH/CA (65/30/5 wt.\%) composite, can be remarked from the well covered rice hulls with PLA and the absence of "neck" formation, indicating that no debonding phenomena occur (micrographs b).

These results make it possible to state that reactive compatibilization allows a significant improvement of the rice hulls-polymer interfacial adhesion. Figure 3 shows SEM micrographs of cryogenically fractured samples of recycled biodegradable PLA-based composites, allowing not only the filler dispersion to be evaluated, but also the filler/matrix adhesion level after an applied external load.

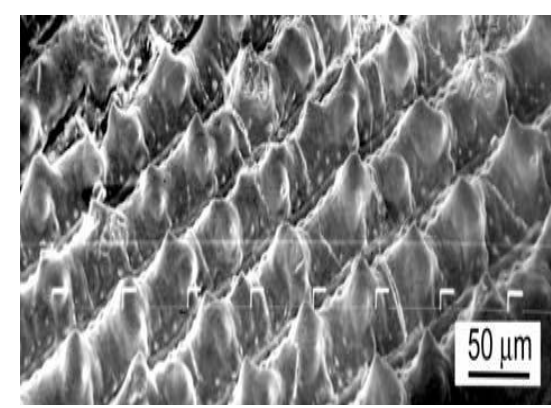

a)

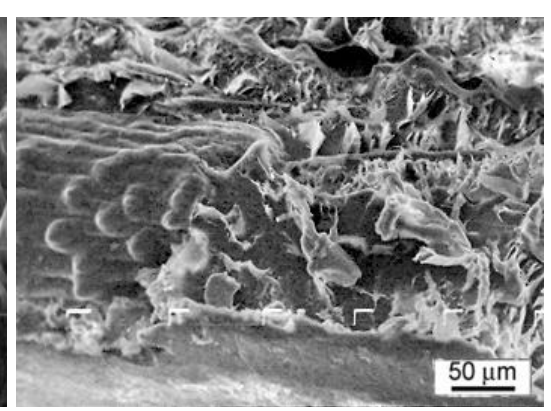

b)

Fig. 2. SEM micrographs of the cryogenically fractured surface for composites:

a) PLA/RH (70/30 wt.\%) without coupling agent and b) PLA/RH/CA (65/30/5 wt.\%) with coupling agent 

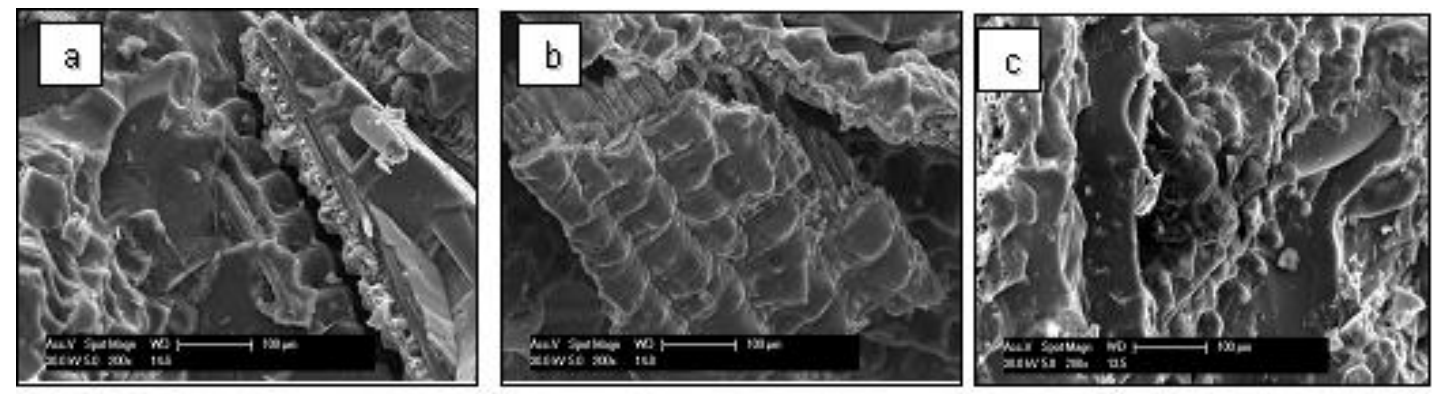

Fig. 3. SEM micrographs of cryogenically fractured surfaces for composites: a) PLA $(\times 1) / \mathrm{RH} / \mathrm{CA}(65 / 30 / 5$ wt. $\%)$; b) PLA/RH/CA $(\times 1)(65 / 30 / 5$ wt. $\%)$;

c) $\mathrm{PLA} / \mathrm{RH} / \mathrm{CA}(65 / 30 / 5$ wt. $\%)(\times 2)$

Concerning PLA-based biocomposites, the cellular structure of rice hulls embedded in the polymer matrix is clearly observed, both for neat and recycled composite samples. No significant differences were noticed in the morphology of the composites after recycling, thus indicating that further processing does not induce any relevant changes in the interfacial adhesion between rice hulls and the PLA matrix. This finding is in agreement with the results obtained for the mechanical properties and thermal behavior recorded for PLA-based composites after the recycling processes.

\section{CONCLUSION}

On the basis of the results obtained for the mechanical properties and thermal behavior of PLA-based biocomposites produced from neat matrix, recycled matrix and from wholly recycled composite, the following conclusions can be drawn.

The rice hulls, representing agricultural waste derived from rice-production, could be used as a biodegradable eco-friendly filler, to minimize environmental pollution and the cost of the final product rather than as reinforcement of the PLA matrix. Introduction of 5 wt.\% PLA-g-MA improved the strength of PLA-based composites with $30 \mathrm{wt} . \%$ rice hulls, as a result of enhanced interfacial adhesion. Considering the flexural properties, the introduction of the recycled PLA matrix in biocomposites decreases the material strength, although the flexural properties of wholly recycled biocomposites are very close to those of the neat ones. Morphological analyses carried out by SEM have revealed that the morphology of PLAbiocomposites is not significantly affected by reprocessing. The thermal stability of the biocomposites produced with recycled matrices or by reprocessing from wholly recycled composites is not significantly affected by the first recycling process. Therefore, it could be recommended as a procedure for the further utilization of these materials after their life time. The recycled PLA matrix and biodegradable PLA-based biocomposites represent a good potential for utilization after recycling. The results obtained for flexural strength and modulus of the recycled biocomposite samples are comparable to those of conventional formaldehyde wood medium density fiberboards which are used as construction elements for indoor applications.

Our further analyses are concerned with investigation of the possibilities of improving their stability during the re-processing cycle.

Acknowledgments. This work is a follow-up of a successfully completed ECO-PCCM project which was financially supported by the EU FP6-INCO-WBC program (INCO-CT2004-509185). The production and characterization of the compressed polymer eco- and biocomposites were carried out in "11 Oktomvri-Eurokompozit" - Prilep, Macedonia. Thermal and morphological analysis was performed at the Institute of Chemistry and Technology on Polymers-ICTP-CNR, Italy. The authors are very grateful to all of these institutions for their support in the fulfillment of this research.

\section{REFERENCES}

[1] Y. Chen, L. S. Chiparus, I. Negulescu, D. V. Parikh, T. A. Calamari, Natural Fibers for Automotive Nonwoven Composites, J. of Ind. Text. 35, 1, 47-61 (2005).

[2] G. Bogoeva Gaceva, D. Dimeski, V. Srebrenkoska, Biocomposites based on PLA and kenaf fibers: Effect of fibrillated celulose, Maced. J. Chem. Chem. Eng. 32 (2), 331-335 (2013).

[3] Seung-Hwan Lee, Siqun Wang, Biodegradable polymers/bamboo fiber biocomposite with bio-based coupling agent, Compos. Part A 37, 80-91 (2006).

[4] K. Oksman, High quality flax fibre composites manufactured by the resin transfer moulding process, J. Reinf. Plast. Compos. 20 (7), 621 (2001).

[5] K. Oksman, M. Skrifvars and J. F. Selin, Natural fibers as reinforcement in polylactic acid (PLA) composites, Compos. Sci. and Techn. 63, 1317-1324 (2003).

[6] G. Bogoeva-Gaceva, A. Bužarovska, Rapid method for evaluation of cure kinetics of thermoseting polymers, Maced. J. Chem. Chem. Eng. 32 (2), 337-344 (2013). 
[7] K. Oksman, Mechanical properties of natural fibre mat reinforced thermoplastics, Appl. Compos. Mat. 7, 403414 (2000)

[8] S. Serizawa, K. Inoue, M. Iji, Kenaf-fiber-reinforced poly(lactic acid) used for electronic products, J. App. Polym. Sci. 100, 618-624 (2006).

[9] Z. Xia, W. A. Curtin, and T. Okabe, Shear-lag versus finite element models for stress transfer in fiber-reinforced composites, Compos. Sci. Technol. 62, 1279 (2002).

[10] H. S. Yang, D. J. Kim, J. K. Lee, H. J. Kim, J. Y. Jeon and C. W. Kang, Possibility of using waste tire composites reinforced with rice hulls as construction materials, Biores. Technol. 95, 61-65 (2004b).

[11] A. K. Mohanty, L. T. Drzal, and M. Misra, Engineered natural fiber reinforced polypropylene composites: influence of surface modifications and novel powder impregnation processing, J. Adhes. Sci. Tech. 16, 999 (2002).

[12] T. J. Keener, R. K. Stuart, and T. K. Brown, Maleated coupling agents for natural fibre composites, Compos., Part A, 35, 357 (2004).

[13] A. N. Netravali and S. Chabba, Composites get greener, Mater. Today 6(4), 22 (2003).

[14] V. Srebrenkoska, G. Bogoeva Gaceva, D. Dimeski, Preparation and recycling of polymer eco-composites, I Comparison of the conventional molding techniques for preparation of polymer eco-composites, Maced. J. Chem. Chem. Eng. 28 (1), 99-109 (2009).

[15] M. Avella, M. Cocca, M. Emanuela Errico, G. Gentile, Polyvinyl alcohol biodegradable foams containing cellulose fibres, J. Cell. Plast. 48 (5),459-470 (2012).

[16] http://www.cargilldow.com. This is the official web site of the Cargill Dow LLC. (Accessed 2013).

[17] M. Avella, G. Bogoeva-Gaceva, A. Bužarovska, M. E. Errico, G. Gentile, A. Grozdanov, Poly(lactic acid)based biocomposites reinforced with kenaf fibers, $J$. Appl. Polym. Sci. 108, 3542-3551 (2008).

[18] M. Avella, G. Bogoeva-Gaceva, A. Bužarovska, M. E. Errico, G. Gentile, A. Grozdanov, Poly(3-hydroxybutyrate-co-3-hydroxyvalerate-based biocomposites reinforced with kenaf fibers. J. Appl. Polym. Sci. 104, 3192-3200 (2007).

[19] B. Dimzoski, G. Bogoeva-Gaceva, G. Gentile, M. Avella, A. Grozdanov, Polypropylene based $\mathrm{ec}^{\mathrm{o}}$-composites filled with agricultural rice hulls waste. Chem. Biochem. Eng. Quarterly. 23 (2), 225-230 (2009).

[20] G. Bogoeva-Gaceva, A. Grozdanov, A. Bužarovska, Eco-friendly polymer composites based on poly- propylene and kenaf fibers, Proceedings of the 3rd International Conference on Eco Composites, Royal Institute of Technology, Stockholm, Sweden, June 20-21, 2005.

[21] A. Grozdanov, A. Buzarovska, G. Bogoeva-Gaceva, M. Avella, M. E. Errico and G. Gentille, Rice hulls as an alternative reinforcement in polypropylene composites, Agron. Sustain. Dev. 26, 251-255 (2006).

[22] ECO-PCCM, FP6-INCO-CT-2004-509185.

[23] A. Grozdanov, A. Bužarovska, G. Bogoeva-Gaceva, M. Avella, M. E. Errico, G. Gentile, Nonisothermal crystallization of kenaf fiber/polypropylene composites, Polym. Eng. and Sci. 47, 745-749 (2007).

[24] B. Dimzoski, G. Bogoeva-Gaceva, G. Gentile, M. Avella, M. E. Errico, V. Srebrenkoska, Preparation and characterization of poly(lactic acid)/rice hulls based biodegradable composites, J. Polym. Eng. 28, 369-384 (2008).

[25] G. Bogoeva-Gaceva, A. Grozdanov, A. Buzarovska, Nonisothermal crystallization of maleic anhydride grafted PP: comparison of different kinetic models, Proceedings of the 5th International Conference of the Chemical Societies of South-East European Countries ICOSECS-5, September 10-14, Ohrid, Macedonia, 2006, pp. 619.

[26] G. Bogoeva-Gaceva, A. Grozdanov, B. Dimzoski, Analysis of the reaction of modified polypropylene in melt, Proceedings of European Polymer Congress EPF, July 2-6, Portorož, 2007.

[27] A. Bužarovska, G. Bogoeva-Gaceva, A. Grozdanov, M. Avella, Crystallization behavior of polyhydroxybutyrate in model composites with kenaf fibers, J. Appl. Polym. Sci. 102 (1), 804-809 (2006).

[28] A. R. Sanadi, J. F. Hunt, D. F. Caulfield, G. Kovacsvologyi, and B. Destree, High fiber-low matrix composites: kenaf fiber/polypropylene, Proceedings of the 6th International Conference on Woodfiber-Plastic Composites, Madison, Wisconsin, May 15-16, 2001.

[29] H. S. Kim, H. S. Yang, H. J. Kim, H. J. Park, Thermogravimetric analysis of rice husk flour filled thermoplastic polymer composites, J. Therm. Anal. Calorim. 76, 395-404 (2004).

[30] R. Avolio, I. Bonadies, D. Capitani, M. E. Errico, G. Gentile, M. Avella, A multitechnique approach to assess the effect of ball milling on cellulose, Carbohyd. Polym. 87 (1), 265-273 (2012).

[31] S. H. Lee, S. Wang, Biodegradable polymers/bamboo fiber biocomposite with bio-based coupling agent, Compos., Part A, 37, 80-91 (2006). 
